\title{
Rock Balancing Land Art: A More-than-Human Approach
}

\author{
石头平衡 : 道法自然的大地艺术 \\ Jun $\mathrm{Hu}$ \\ Hangzhou Normal University, China
}

\begin{abstract}
As it happened during the Covid-19 pandemic in the spring of 2020, the art of balancing rocks had therapeutic effect of comforting me. It was the physical law of balance that had taken psychological effect through my performance of keeping rocks in balance. Setting out as an incidental and personal art practice in the beginning, it evolved quickly into an improvisational community art project, attracting hundreds of participants who together turned a torn embankment into a gallery of land art, bringing joy and consolation to each other during the difficult period. The dynamics behind that improvisational artistic activity reminds me of the traditional Chinese philosophy of Tao-follows-nature (道法自然) that implies a more-than-human approach of art education. A retrospect into the rock art project and a study into Shan-Shui (山水), literally "mountain and water," the genre of classical Chinese landscape painting, come up with an alternative understanding of art education that does not count on the teaching of a human teacher, but on a sensational leaning process empowered by the nature, which was compared to an artist's surrogate pregnancy for the nature by Shitao, a Chinese art philosopher, in the $17^{\text {th }}$ century.
\end{abstract}

Keywords: pedagogy, more-than-human, art, Tao

\section{摘要}

在2020年春季新冠大流行期间，平衡岩石的艺术行为对我产生了具有安慰作用的 治愈效果。当我努力保持岩石平衡时，物理学意义上的平衡定律发挥了心理学意义 上的平衡作用。最初，它只是我偶然的、个人的艺术实践，但是很快演变成一个自 发的社区艺术项目，吸引了数百名参与者。他们一起把一条破碎的堤坝变成了一个 大地艺术的画廊，在那个艰难时刻给彼此带来了欢乐和慰藉。这个自发社区艺术 背后的动能，让我重新思考中国传统哲学思想 “道法自然”，及其所暗示的一种“ 超出人类" 的艺术教育方式。回顾岩石平衡艺术项目，研究中国古典山水画体裁，可以得出对艺术教育的另类理解一一不依赖于人类教师的教授，而是依赖于自然赋能的 感性学习。这种学习方式，在17世纪山水画家石涛的《苦瓜和尚画语录》中表述为“山 川使予代山川而言也，山川脱胎于予也，予脱胎于山川也。”

关键词: 山水, 道, 自然, 教学法

At the peak of the first wave of the Covid-19 pandemic in the spring of 2020, I happened to be in Montreal, Canada, and as Asian, I experienced a radical situation of isolation. Despite the social distance enforcement, the situation was made worse by the anti-Asian prejudice and discrimination caused by some politician's intentional holding on to the term of "Chinese virus" despite World Health Organization disapproval. Those factors 
made me, an artist, a researcher, and a teacher, feel the responsibility to engage the frustrating situation from my professional stand. I was looking for an artful way that can draw people closer for solidarity while abiding by the social distancing measures.

It all happened by chance that I found solution inspired by two kids' playing with rocks to build inuksuk at the waterfront of St. Louis Lake at Lachine Park in my neighborhood. Inuksuk means "like human" in the language of the Inuit, the aboriginal people living in the North Arctic. Inuksuk is the rock art, often in human appearance, that functions as landmark indicating orientation for travelers on the vast ice land. It was touching to me, for I, feeling isolated like a lonely traveler on ice land, needed orientation. The inuksuk with extended arms was a sign of hospitality to me (Figure 1).

To return the favor, I started to make my rock art. I chose the rock balancing style I saw on YouTube (e.g., https://www.youtube.com/watch?v=UqU19dR0bFE). It is an art to make rocks stand on a tiny tip in equilibrium and to pile rocks up without using any adhesive or support to maintain them in position (Figure 2). It took me a while to master the craft, because it is extremely difficult to find the center of mass of each rock and to match it with a tiny support point. It requires great patience, and any small mistake could make the rocks fall, and you have to start all over again. However, once I

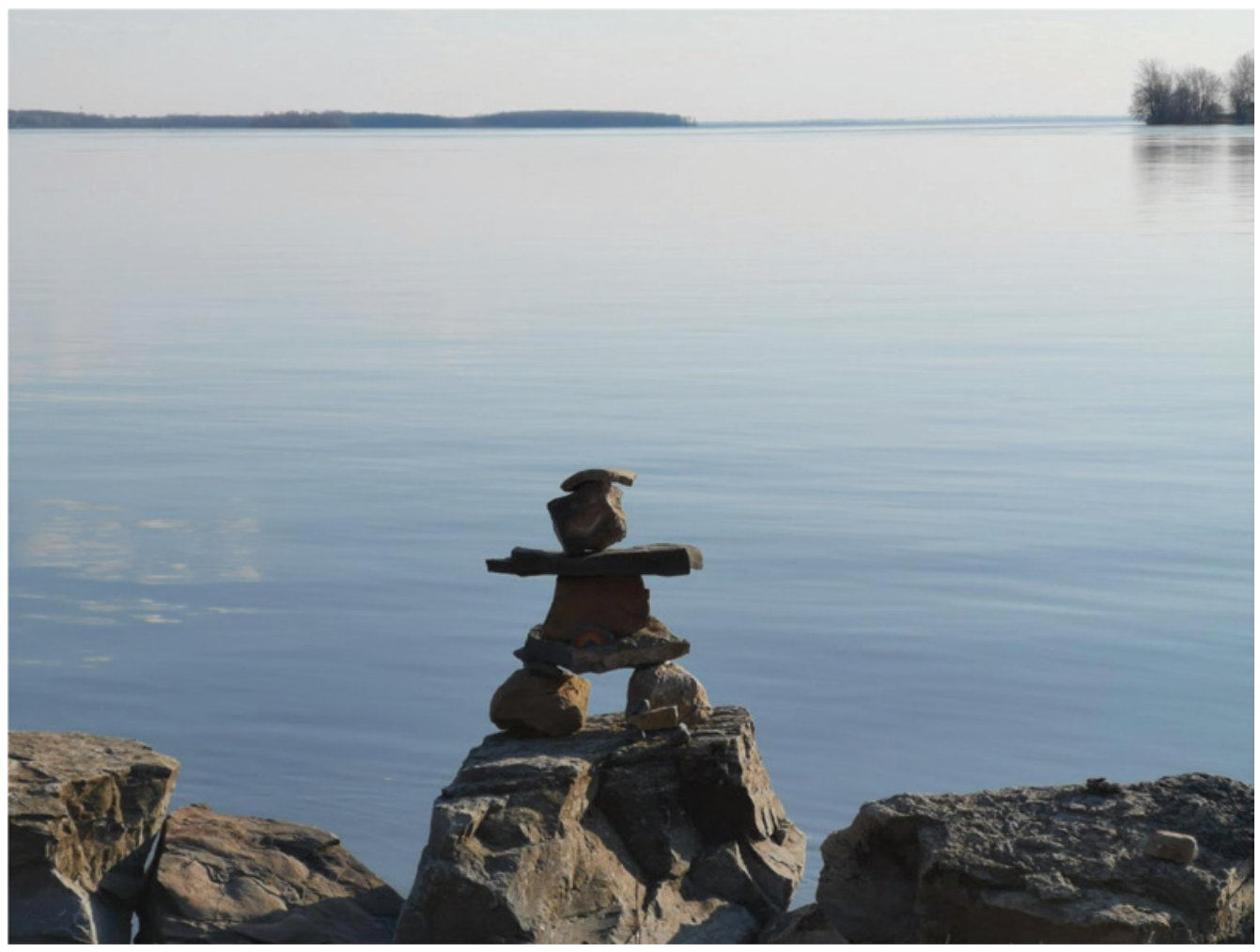

FIGURE 1 | Inuksuk, man-like North Arctic indigenous style rock art at Lachine Park in the spring of 2020 (creator unknown). 


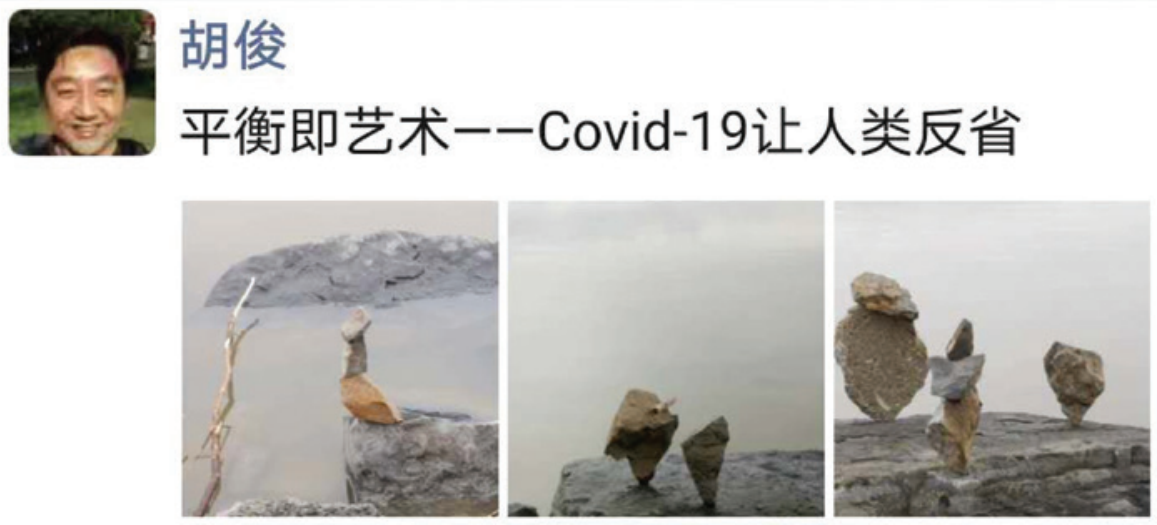

FIGURE 2 | Jun Hu's rockbalancing art published in his minute of WeChat, April 7, 2020.

succeeded, I felt a magical relaxation. Having fun in it, I worked on it on daily basis as long as the weather permitted.

To my surprise, many passers-by thanked me for what I had been doing, saying that my rock balancing art had a comforting power to them. More surprisingly, more and more people joined in to make their own rock art at the waterfront. Before long, this incidental art practice became an improvisational community land art project. Hundreds of anonymous participants turned the several kilometers long bank of St. Louis lake into an art gallery of rock art of varied styles (Figure 3), which had cheered people up throughout the spring until the pandemic waned and social distance restrictions lessened in the summer.

In hindthought, I assume that the development of this improvisational community land art has two pedagogical implications: one is that natural disaster could be art in itself; the other is that art education may not need a human teacher. Both resonate an Asian philosophy of Tao-follows-nature (道法自然) that supports a more-than-human approach to art education.

In fact, most magnificent natural wonders are the consequences of natural disasters, such as mountains of volcano, gorges of earthquake, lakes of flood, deserts of drought, etc. We cannot help feeling esthetic awe when we see those wounds of the earth or amazed by how Mother Nature rehabilitates them. In this sense, natural disaster, and
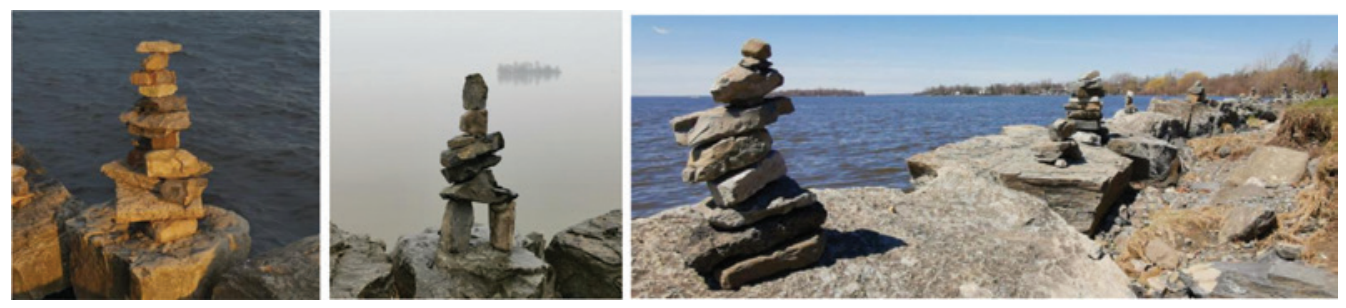

FIGURE 3 | Works at Lachine Park, spring of 2020 (creator unknown). 
its natural rehabilitation, is art in itself. The community rock art started from the coincidence of two natural disasters: One was the landslide caused by the heavy ice and snow last winter, and the other was the devastating Covid-19 pandemic. When the embankment of the lake was broken and slid into the water, it left a deep trench several kilometers long with debris of rocks. When social distancing measures were enforced to stop the spread of Covid-19, an invisible "trench" was left between people. Both disasters left with wounds to be cured, and the rock art happened to be the cure for both. It is like Mother Nature's rehabilitation of its wounds; the rock art has not only turned the broken embankment into a new landscape but also has drawn people closer spiritually despite spatial distancing. In this sense, the rock art is the consequence of the two disasters, which explains the fact, too, that the artistic activity came to a stop in the summer when the park was alive again with flowers and wildlife and when there were much more public activities as social distancing measures were lessened. It stopped as it started without any instructor to give order, for it is nature' running its own course from disaster to rehabilitation.

As nature runs its own course, we are participants involved in the nature's course through art-making. This put me into contemplation of the possibility of an art pedagogy that is more than human.

I assume that art education may be re-conceptualized within a logic that makes possible an improvisational creativity without conscious purpose of the artist beforehand and that teaching as such could be conducted without an art teacher, or a community art project without an organizer. This logic reminds me of the traditional Chinese philosophy of Tao-follows-nature and its practices in the so-called literati art of Shan-Shui (山水, literally “mountain and water"), the traditional genre of East Asian landscape painting with the minimalist art media of ink and water.

Tao-follows-nature has been the guiding principle of Chinese art, but what is Tao? Tao defies definition according to Taoist philosophy. Tao can be literally translated into "methods" or "path," but not exactly, for Tao is nothing concrete or that can be pinned down by words. It might be better translated as a methodology of situations. Tao is a relatedness that situates human activity and the nature alike. By Tao-follows-nature, it assumes a methodology for creativity that counts on the consciousness of interrelations between human and nature, and that interrelations exists universally in the nature.

It is my experience that rock balancing is an art situated in such interrelations. It is almost impossible to predict what the final outcome should be like due to the irregular shapes of rocks and the extreme difficulty in finding the support point. To start with rock balancing, representational thinking has to come to a stop and is replaced by a bodily sensation. At the touch of the fingertip on the rock, the natural world outside is linked to the body space inside. To make the rock stand, one has to be highly concentrated and to hold breath, which culminates at the moment when the fingertip leaves the rock to let it stand by itself. It is a moment when all attention is paid to the pressure felt by the fingertip on the rock, especially when the pressure comes to zero, a balanced state between inside and outside that leaves the rock standing on its own. At that moment, an intuitive learning process takes place - the physical law of balance being embodied as my bodily sensation - with the esthetic consequence of the rock standing in balance 
(Figure 4). That learning is nothing verbal or didactic, but the intuitive awareness of a meaning that is relational between me and nature, in form of a bodily sensation. The physical law of balance is nothing extraordinary to human experience, but it has often been integrated into all other senses without conscious awareness. Rock balancing brings this to conscious awareness in a relational way between me and nature. The final posture of rock balancing comes not out of my will, but of a newly established dialectic relation between me and nature (Figure 5). In this process, the nature plays

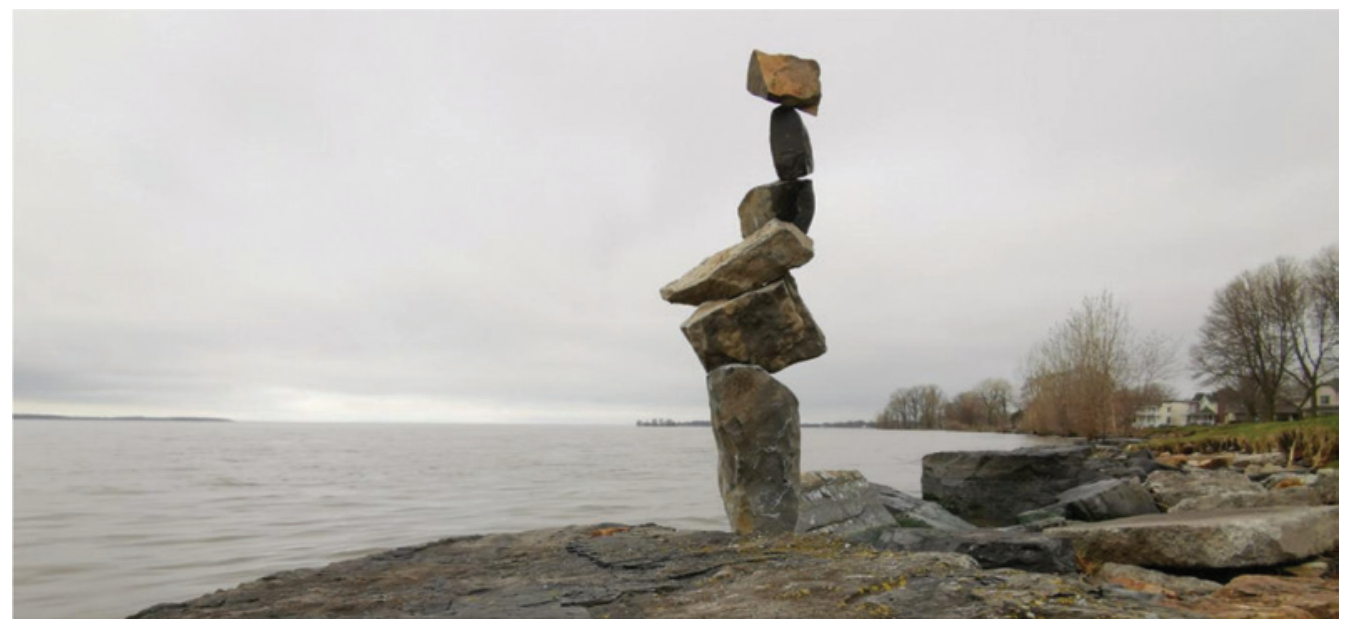

FIGURE 4 | Jun Hu's work of rock balancing.

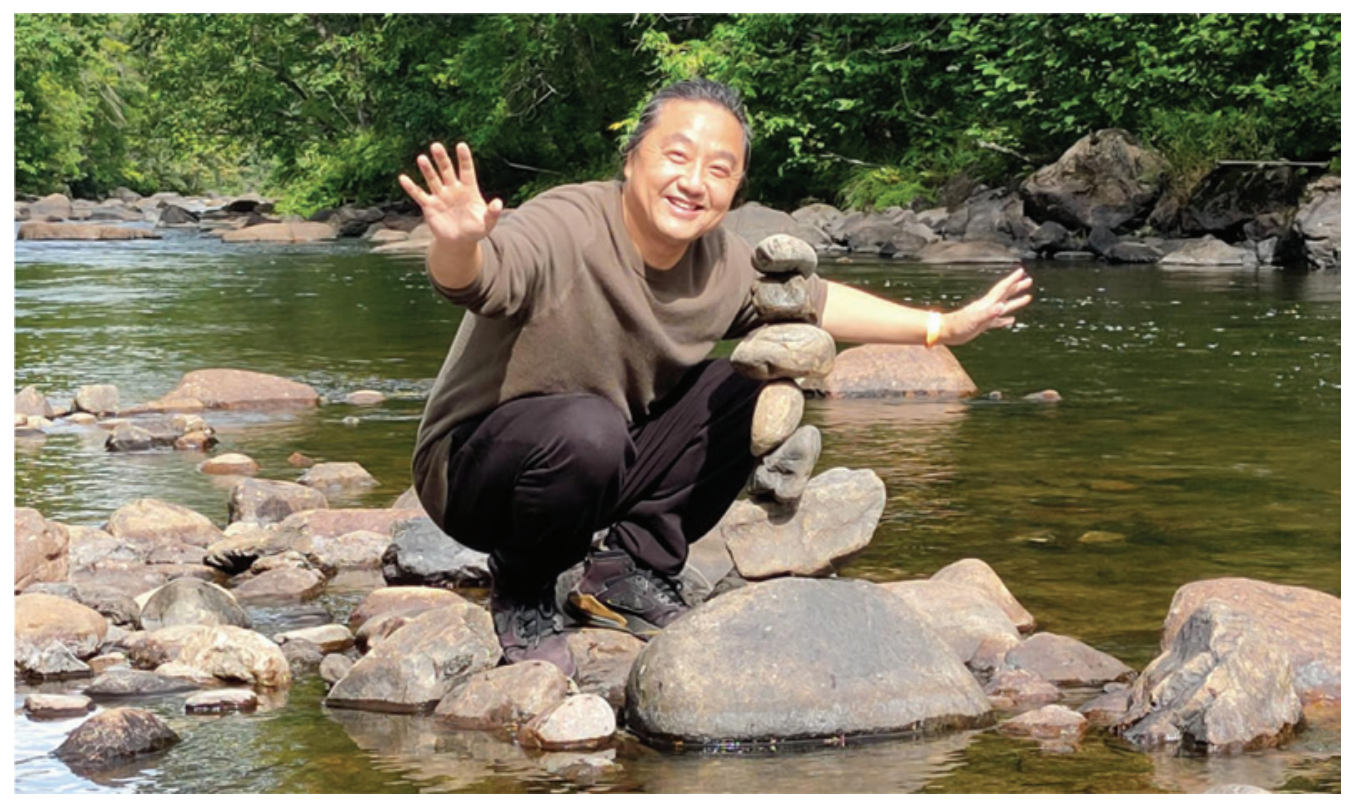

FIGURE 5 | Jun Hu's performance of rock balancing. 
an active role rather than merely a background of human activity or passive object of human exploitation and manipulation. With the nature playing the active role, the construction of rock balancing art is not the fulfillment of a design beforehand, but rather an unpredictable process that is playful, meditative, and collaborative, affirmed by a radical relational esthetics of joy (Spinoza, 2018). As the performance of the rock balancing involves positioning, balancing, and securing, which are metaphors of the essentials of my being in the difficult situation of the pandemic, it naturally has a therapeutic effect on me. When I watched the kids playing with inuksuk or when others watched me balancing rocks, there was an overlapping of this dialectic relation that connected me to others in this same relation with the nature as well that sparked off a community art without an organizer.

This approach of art counts its esthetics on its feature of performance-and-making as one in the process rather than a representative outcome, so does shanshui painting. It is not the goal of shanshui painters to deliver a naturalistic representation of the landscape, but to master Tao by playing with ink and water to learn the law of nature. That goal of art is unfamiliar to the Western artist, but has been popular in the art practice of Chinese intellectuals for over a thousand years and has a therapeutic effect to the essentials of their being in the world. Idealist solidity and realistic pliability are the two necessary virtues of an intellectual who is to carry out Confucian political ideal and to survive the unfavorable world. The two art materials of ink and water each affords the embodiment of a virtue indispensable to a Confucian intellectual. The artistic interaction between ink and water in shanshui painting emulates the natural interaction between earth and water in the nature's making of landscape, and the literati artist is supposed to take a moral lesson from the performance and making of shanshui painting. Ink is for the abstraction of earth, which has the quality of firmness in varied actualized forms of hills, mountains, and rocks. Water has the quality of pliability in its varied actualization of rivers, lakes, waterfalls, etc. that reach the ocean despite any obstacle. During the painting process, the qualities of firmness in mountain and pliability in water are embodied by the literati painter as the virtues of a resilient noble man and their interrelations as the political wisdom to keep dynamic balance between idealism and realism. Painting shanshui, mountain-and-water, with esthetic satisfaction, the painter demonstrates a mastery of Tao, the political wisdom learned from Mother Nature.

Because of that Tao-follows-nature feature of shanshui painting, the esthetic criteria of shanshui painting are distinctively different from those of landscape painting in the classical Western art. From the classical Western perspective, Chinese shanshui painting might look too simple in its representation and too naive in imagery, but it serves well the ancient Chinese intellectuals' goal of pursuing Tao. Because shanshui painting takes effect through the performance of painting and counts on the interplay between ink and water instead of its representational outcome, shanshui painters treasure brushwork and take on an abstract expressionist style, which, in some radical cases, are precursors of Jackson Pollock's action painting in 1950s.

In Shitao's (石涛, 1642-1707 AD) essay on the learning of shanshui painting, he compares the painting process to pregnancy and delivery, and the painter' role to the 
nature's pregnancy surrogate, to describe how literati painters achieve transformation through the embodied sensation, empowered by the nature. He wrote: "It is the mountain and the river who make me speak for them. I deliver my baby of shanhui painting, but my baby is the child of mountain and water." ${ }^{\prime \prime}$ This metaphor of pregnancy surrogate is a vivid description of the painter's embodiment of Tao as establishing relatedness between human and nature.

When I make rock balancing arts, between me and the nature, there is the becoming of a third place that is infused with the fluidity of potentialities and possibilities, as if I am playing the role of pregnancy surrogate. I deliver the rock balancing art to the world, but it does not come out of my design but out of my interaction with nature that passes the physical law of balance through my performance. Pregnancy surrogate is a humorous but insightful metaphor for this Tao-follows-nature engagement that enables the performer the psychological transformation through embodiment.

Tao-follows-nature, as an approach of art education, opposes the narcissistic understanding of art teaching that is human-centered, but supports instead a morethan-human understanding that counts on nature's empowering process for learning that is situated in the interrelations between man and nature. A learning as such does not need to be semantically understood, for it is comprehended in a relational way and is sensationally embodied by the one who acts the role of pregnancy surrogate. Although it does not resort to psychological means, it does have a psychological effect by ecological means. Although there is no need of a human teacher, this more-thanhuman approach arouses human sensation through human embodiment. Ecological and more-than-human, the pedagogy, as demonstrated in the community rock art and the literati shanshui painting, enhances participants' psychological welfare and social relationships by establishing interrelations between human and nature.

To sum up, Tao-follows-nature cherishes nature as the non-human "great and most honored master," as described in Taoist philosopher Chuang-tzu's (庄子, 369-286 BCE) essay: "There is in it emotion and sincerity; but it does nothing and has no bodily form. It may be handed down, but may not be received. It may be apprehended by the mind but may not be seen. It has it root and ground (of existence) in itself. Before there were heaven and earth, from of old, there it was, securely existing. 'ii (translated by James Legge, 1891).

"There is in it emotion and sincerity" because it functions through bodily sensation. "It does nothing and has no bodily form" because it is relational between man and nature without any solid form. "It may be handed down, but may not be received" because it is knowing-and-being as one process, a living experience of surrogate pregnancy, rather that the taking and giving of knowledge. "It may be apprehended by the mind but may not be seen" because it is that which is relational and defies definition. "It has it root and ground (of existence) in itself. Before there were heaven

\footnotetext{
i Original text in Chinese : “山川使予代山川而言也，山川脱胎于予也，予脱胎于山川也。” ( 石涛《苦瓜和尚画语录》山川章第八)

ii Original text in Chinese : “有情有信，无为无形，可传而不可受，可得而不可见。自本自根， 未有天地，自古以存”。(《庄子·大宗师》)
} 
and earth, from of old, there it was, securely existing" because it is the nature's being and becoming itself.

\section{About the Author}

Dr. Jun $\mathrm{Hu}$ is the chair of the Art Education Department and dean of A/r/tography Research Center of Hangzhou Normal University, chair of the Asian Regional Council of International Society for Education through Art (InSEA), and a member of the Autism Professional Committee of Zhejiang Neuroscience Society. He considers himself an a/r/ tographer that resides in the liminal spaces in-between the artist, the researcher, and the teacher, drawing inspiration and knowledge out of their mutual impact. His research interest includes comparative study between Eastern and Western philosophies of art education and pedagogical application of a/r/tography in the field of art teachers education and social service-oriented art education. As founder of $\mathrm{A} / \mathrm{r} / \mathrm{tLink}$ Charity Project, his art therapy projects have won national and international recognition for functionality and ingenuity, including the "In/visible," which enables blind kids to engage in art, autistic children's rehabilitation through interactive art, and the "Light through Wall," which helps juvenile inmates to re-create identity through light painting.

\section{Conflicts of Interest}

The author declares no conflict of interest.

\section{References}

Spinoza, B. (2018). Spinoza: Ethics: Proved in geometrical order. Cambridge, UK: Cambridge University Press, 2018.

石涛 (2007).苦瓜和尚画语录. 济南: 山东画报出版社.

Shi Tao. (1969). (17th Century A.D.). An expressionist credo. In Y. Lin (trans.), The Chinese theory of art: Translations from the masters of Chinese art (pp. 147-166). London: Panther.

Chinese Text Project: Chuang-tzu. The great and most honoured master. J. Legge (Trans.), 1891. Available online: https://ctext.org/zhuangzi/great-and-most-honoured-master/zhs?en=on (accessed 2 December 2021). 